\title{
Article \\ Hydrogen Nano-Bubble Water Suppresses ROS Generation, Adipogenesis, and Interleukin-6 Secretion in Hydrogen-Peroxide- or PMA-Stimulated Adipocytes and Three-Dimensional Subcutaneous Adipose Equivalents
}

\author{
Li Xiao ${ }^{1, *(D)}$ and Nobuhiko Miwa ${ }^{2}$ (D) \\ 1 Department of Pharmacology, School of Life Dentistry at Tokyo, Nippon Dental University, \\ Tokyo 102-8159, Japan \\ 2 Faculty of Life Sciences, Prefectural University of Hiroshima, Hiroshima 727-0023, Japan; \\ jpn.cntr.antiaging.medsci2002@leto.eonet.ne.jp \\ * Correspondence: xiaoli@tky.ndu.ac.jp; Tel.: +81-3-3261-8772
}

\section{check for}

updates

Citation: Xiao, L.; Miwa, N. Hydrogen Nano-Bubble Water Suppresses ROS Generation, Adipogenesis, and Interleukin-6 Secretion in Hydrogen-Peroxide- or PMA-Stimulated Adipocytes and Three-Dimensional Subcutaneous Adipose Equivalents. Cells 2021, 10, 626. https://doi.org/

10.3390/cells10030626

Academic Editor: Robert Friesel

Received: 16 February 2021

Accepted: 9 March 2021

Published: 11 March 2021

Publisher's Note: MDPI stays neutral with regard to jurisdictional claims in published maps and institutional affiliations.

Copyright: (c) 2021 by the authors. Licensee MDPI, Basel, Switzerland. This article is an open access article distributed under the terms and conditions of the Creative Commons Attribution (CC BY) license (https:/ / creativecommons.org/licenses/by/ $4.0 /)$.

\begin{abstract}
Reactive oxygen species (ROS)-induced oxidative stress in adipose tissue is associated with inflammation and the development of obesity-related metabolic disorders. The aim of this study is to investigate the effects of hydrogen nano-bubble water (HW) on ROS generation, adipogenesis, and interleukin-6 (IL-6) secretion in hydrogen peroxide $\left(\mathrm{H}_{2} \mathrm{O}_{2}\right)$ or phorbol 12-myristate 13-acetate (PMA)-stimulated OP9 adipocytes, and three-dimensional (3D) subcutaneous adipose equivalents. Nanoparticle tracking analysis showed that fresh HW contains $1.17 \times 10^{8} / \mathrm{mL}$ of nano-sized hydrogen bubbles. Even after 8 to 13 months of storage, approximately half of the bubbles still remained in the water. CellROX ${ }^{\circledR}$ staining showed that $\mathrm{HW}$ could diminish $\mathrm{H}_{2} \mathrm{O}_{2}$ - or PMA-induced intracellular ROS generation in human keratinocytes HaCaT and OP9 cells. We discovered that PMA could markedly increase lipid accumulation to $180 \%$ and IL-6 secretion 2.7-fold in OP9 adipocytes. Similarly, $\mathrm{H}_{2} \mathrm{O}_{2}(5 \mu \mathrm{M})$ also significantly stimulated lipid accumulation in OP9 cells and the 3D adipose equivalents. HW treatment significantly repressed $\mathrm{H}_{2} \mathrm{O}_{2}$ - or PMA-induced lipid accumulation and IL-6 secretion in OP9 adipocytes and the 3D adipose equivalents. In conclusion, HW showed a possibility of repressing oxidative stress, inflammatory response, and adipogenesis at cellular/tissue levels. It can be used for preventing the development of metabolic disorders amongst obese people.
\end{abstract}

Keywords: hydrogen-rich water; nano-bubbles; hydrogen peroxide; phorbol 12-myristate 13-acetate; IL-6; reactive oxygen species; adipogenesis; adipose equivalents; inflammation; metabolic disorders

\section{Introduction}

Obesity-induced metabolic disorders have been shown to lead to the development of type 2 diabetes mellitus and cardiovascular diseases [1-3]. Obesity is characterized as excessive fat accumulation in both adipose and non-adipose tissues [4]. Fat-accumulationaccompanied oxidative stress is the main contributor to the development of metabolic disorders in obesity [5,6]. Oxidative stress is caused by over-produced reactive oxygen species (ROS), which overwhelms the antioxidant defense systems in the organism $[7,8]$. ROS also act as intracellular redox messengers in the regulation of numerous signaling pathways ranging from cell homeostasis and cell differentiation to cell death [9]. ROS include superoxide anion $\left(\mathrm{O}_{2}^{\bullet-}\right)$, hydroxyl radicals $(\bullet \mathrm{OH})$, hydrogen peroxide $\left(\mathrm{H}_{2} \mathrm{O}_{2}\right)$, and hydroperoxyl radicals (HOO•). Evidence show that oxidative stress of vascular origin caused by hydrogen peroxide initiates body fat accumulation [10,11]. As the body fat expands, adipocytes and non-adipocytes (such as hepatocytes and muscle cells [12]) generate ROS. ROS-caused oxidative stress stimulates the secretion of inflammatory cytokines (such as interleukin-6 (IL-6) and tumor necrosis factor (TNF)-alpha) and adipokines, which leads to insulin resistance and other metabolic disorders [13-15]. Therefore, the use of 
antioxidants to inhibit oxidative stress might stop oxidative-stress-caused adipogenesis and the release of inflammatory cytokines and thus prevent metabolic disorders.

During the past decade, molecular hydrogen $\left(\mathrm{H}_{2}\right)$ has gained attention as a therapeutic and preventive antioxidant by inhibiting oxidative stress in most organs [16]. Hydrogen can convert the toxic ROS, hydroxyl radicals, superoxide anion, and hydrogen peroxide to harmless water $\left(2 \bullet \mathrm{OH}+\mathrm{H}_{2} \rightarrow 2 \mathrm{H}_{2} \mathrm{O}, \mathrm{O}_{2}{ }^{\bullet-}+2 \mathrm{H}_{2} \rightarrow 2 \mathrm{H}_{2} \mathrm{O}, \mathrm{H}_{2} \mathrm{O}_{2}+\mathrm{H}_{2}\right.$ $\rightarrow 2 \mathrm{H}_{2} \mathrm{O}$ ). It was reported that hydrogen also has anti-inflammatory effects and stimulates the energy metabolism. In this study, we tested the effects of hydrogen-bubbling water named Hexa Z Hydro-Nano-Bubble Water $(\mathrm{HW})$ on hydrogen peroxide $\left(\mathrm{H}_{2} \mathrm{O}_{2}\right)$ or phorbol-myristate-acetate (PMA; an inducer of endogenous superoxide anion and hydrogen peroxide)-induced ROS generation, lipid accumulation, and IL-6 secretion in OP9 adipocytes and three-dimensional subcutaneous adipose equivalents.

\section{Materials and Methods}

\subsection{Testing Hydrogen Nano-Bubbles in Hexa Z Hydro-Nano-Bubble Water}

The hydrogen nano-bubble water, named Hexa Z Hydro-Nano-Bubble Water (HW; EBM Co. Ltd., Tokyo, Japan), was prepared by filtrating-extracting of the purified water through Amaterasu stone, which is mineralogically categorized as black mica-quartz obtained from Mt. Takachiho (Prefs. Miyazaki and Kagoshima, Japan), composed of $\mathrm{SiO}_{2}: 66.2(w t / w t \%), \mathrm{Al}_{2} \mathrm{O}_{3}: 13.0, \mathrm{MgO}: 4.99, \mathrm{Na}_{2} \mathrm{O}: 4.06, \mathrm{Fe}_{2} \mathrm{O}_{3}: 2.95, \mathrm{CaO}: 2.45, \mathrm{~K}_{2} \mathrm{O}$ : 1.10, and $\mathrm{TiO}_{2}: 0.44$, with far-infrared radiation of $>86.3 \%$ and atmospheric negative ion emission of $>35$ ions $/ \mathrm{mL}$, thereafter bubbling through high-porosity microporous terminals with hydrogen gas under high pressure, and sterilizing with a filter. HW was packed in screw-capped aluminum bottles and preserved below room temperature. A possibility for formation and existence of water cyclic-hexamer clusters was characterized IR-spectroscopically by Nakamura and Ito [17]. Nano-sized hydrogen bubbles in HW were analyzed using Nanoparticle Tracking Analysis (NTA; Version 2.3 Build 0025, Malvern, UK) with a Nano Sight LM10V-HS system (Malvern Co. Ltd., Malvern, UK). The water samples obtained at different time points were stored at $4{ }^{\circ} \mathrm{C}$ until use. The storage times were 8 months, 13 months, 15 months, and 8 years. Polystyrene latex particles with a diameter of $100 \mathrm{~nm}$ in water were used as standard particles. Each sample was tested 6 times.

\subsection{Cell Culture}

Human immortalized skin epidermal keratinocytes (HaCaT) were kindly provided by Professor Norbert E. Fusenig of the Deutsches Krebsforschungszentrum (Heidelberg, Germany) [18]. Cells were maintained in Dulbecco's modified Eagle's medium (DMEM; Thermo Fisher Scientific, Tokyo, Japan) supplemented with $10 \%$ fetal bovine serum (FBS), 1\% Gibco ${ }^{\circledR}$ GlutaMAX ${ }^{\mathrm{TM}}$ Supplement (Thermo Fisher Scientific, Tokyo, Japan), 100 units $/ \mathrm{mL}$ penicillin, and $10 \mathrm{mg} / \mathrm{mL}$ streptomycin in a $5 \% \mathrm{CO}_{2}$ atmosphere at $37^{\circ} \mathrm{C}$ [19].

OP9 mouse stromal cells (RCB1124) were purchased from the Riken Cell Bank (Saitama, Japan). Cells were cultivated in the propagation medium: MEM- $\alpha$ with $20 \%$ FBS, $1 \%$ Gibco $^{\circledR}$ GlutaMAX TM Supplement (Thermo Fisher Scientific), 100 units $/ \mathrm{mL}$ penicillin, and $10 \mathrm{mg} / \mathrm{mL}$ streptomycin in a $5 \% \mathrm{CO}_{2}$ atmosphere at $37^{\circ} \mathrm{C}$. For adipocyte differentiation, OP9 cells were grown to $100 \%$ confluence in the propagation medium. Cells were then cultivated in KSR medium (MEM- $\alpha$ containing $15 \%$ KnockOut $^{\mathrm{TM}}$ serum replacement, 100 units $/ \mathrm{mL}$ penicillin, $10 \mathrm{mg} / \mathrm{mL}$ streptomycin, and $1 \%$ Gibco $^{\circledR}$ GlutaMAX ${ }^{\mathrm{TM}}$ Supplement) for another $4-6$ days [20].

\subsection{Culture of Subcutaneous Adipose Equivalents}

The subcutaneous adipose equivalents were prepared with a Cellmatrix type I-A culture kit (Nitta Gelatin, Tokyo, Japan) similar to our previous study [20]. Briefly, OP9 cells $\left(1 \times 10^{6}\right.$ cells $\left./ \mathrm{mL}\right)$ were gently added into the type I-A collagen gel mixed with $10 \% 10 \times$ concentrated MEM- $\alpha$ and $10 \%$ reconstruction buffer $\left(2.2 \mathrm{~g}\right.$ of $\mathrm{NaHCO}_{3}$ and $4.47 \mathrm{~g}$ HEPES in $100 \mathrm{~mL} 0.05 \mathrm{~N} \mathrm{NaOH})$. Then, the mixture was seeded into a Falcon ${ }^{\circledR}$ 
24-well culture insert (Corning Inc., Tokyo, Japan) and placed into a 24-well plate. After the mixture was incubated in OP9 cells propagation medium for 3-4 days, HaCaT cells $\left(1 \times 10^{6}\right.$ cells $\left./ \mathrm{mL}\right)$ were seeded into the OP9 collagen gel substrate and the medium was changed to KSR medium containing 5\% FBS. One day later, the medium was replaced with KSR medium containing 1\% FBS. After further cultivation for 4 days, the culture surfaces were exposed to air in the incubator. The culture medium was replaced with KSR medium without FBS twice a week and the cells incubated for another 2-4 weeks.

\subsection{Hydrogen Peroxide and PMA Treatment}

Hydrogen peroxide $\left(\mathrm{H}_{2} \mathrm{O}_{2} 30 \%\right.$; 081-04215, FUJIFILM Wako Pure Chemical Co., Osaka, Japan) and PMA (162-23591; FUJIFILM Wako Pure Chemical Co., Osaka, Japan) were first diluted in double-distilled water (DDW), and then in culture medium just prior to each experiment. For hydrogen peroxide treatment, $\mathrm{HaCaT}$ or OP9 cells were incubated in culture medium with $\mathrm{H}_{2} \mathrm{O}_{2}$ at different concentrations for certain culture periods. Control cells were treated similarly without $\mathrm{H}_{2} \mathrm{O}_{2}$. For PMA treatment, OP9 cells were incubated with PMA $(10 \mathrm{ng} / \mathrm{mL})$ in KSR medium for 4 days. Control cells were similarly treated without PMA.

\subsection{Live/Dead Staining}

Live and dead cells were detected with a Live/Dead ${ }^{\circledR}$ Cell Imaging kit $(488 / 570$; R37601; Thermo Fisher Scientific) according to the manufacturer's protocol. The images were observed with a confocal laser scanning microscope (LSM 700; Carl Zeiss Microscopy Co., Ltd., Tokyo, Japan).

\subsection{Cell Viability Assay}

Cell viability in $\mathrm{HaCaT}$ cells was measured using PrestoBlue ${ }^{\circledR}$ Assay according to the manufacturer's protocol. At the end of cultivation, $\mathrm{HaCaT}$ cells were incubated for $3 \mathrm{~h}$ at $37^{\circ} \mathrm{C}$ in fresh medium supplemented with $10 \%$ PrestoBlue $^{\circledR}(v / v$; A13261, Thermo Fisher Scientific). The PrestoBlue ${ }^{\circledR}$ reduction, expressed as fluorescence intensity units by the cells, was measured using a microplate reader (SH-9000Lab, HITACHI, Tokyo, Japan) with excitation/emission at $560 \mathrm{~nm} / 590 \mathrm{~nm}$ [21].

\subsection{Cellular ROS Detection}

$\mathrm{HaCaT}$ cells were cultivated in DDW- or HW-prepared culture medium for $2 \mathrm{~h}$. The medium was then changed to regular medium containing $\mathrm{H}_{2} \mathrm{O}_{2}$ at different concentrations. At $2 \mathrm{~h}$ after $\mathrm{H}_{2} \mathrm{O}_{2}$ treatment, cellular ROS generation in $\mathrm{HaCaT}$ cells was detected using the CellROX ${ }^{\circledR}$ Orange or Green Reagent (Thermo Fisher Scientific) according to the manufacturer's recommended protocol. ROS production in cells was observed by the EVOS ${ }^{\circledR}$ FL Cell Imaging System (Thermo Fisher Scientific). To qualitatively analyze the ROS production, HaCaT cells were detached from the culture substratum-surface using a $0.25 w / v \%$ trypsin, $1 \mathrm{mmol} / \mathrm{L}$ EDTA solution, and then suspended in PBS (-) at a concentration of $1 \times 10^{6}$ cells $/ \mathrm{mL} .25 \mu \mathrm{L}$ of the cell suspension was infused into a Tali ${ }^{\mathrm{TM}}$ Cellular Analysis Slide (T10794, Thermo Fisher Scientific) and analyzed by the Tali ${ }^{\mathrm{TM}}$ Image Cytometer (Thermo Fisher Scientific) [19].

\subsection{Oil Red O Staining}

Specimens were fixed with $10 \%$ formalin and then stained for $1 \mathrm{~h}$ with filtered solution of $0.25 \%$ Oil Red O in $60 \%$ aqueous 2-isopropanol. After being washed with distilled water, samples were further stained with hematoxylin for $10 \mathrm{~min}$. The images of stained samples were observed with a light microscope (Nikon, Tokyo, Japan). For quantitative analysis of cellular lipid droplets in OP9 cells, hematoxylin staining was omitted. Cellular dye was extracted with $60 \%$ isopropanol using a platform rocker for $30 \mathrm{~min}$. The extracted dye was transferred into a 96-well plate and read for absorbance with a microplate reader (SH-9000Lab, HITACHI) at $530 \mathrm{~nm}$ [22]. For quantitative analysis of cellular lipid droplets 
in 3D subcutaneous adipose equivalents, the images of Oli Red O staining were analyzed using ImageJ software (v1.52, National Institute of Health, Bethesda, MD, USA).

\subsection{Enzyme-Linked ImmunoSorbent Assay (ELISA)}

To determine levels of IL-6 in OP9 cells, samples were analyzed using a commercially available mouse IL-6 ELISA Kit, (RAB0308, Sigma-Aldrich, Tokyo, Japan). At the end of the cultivation process, cell culture supernatants were collected and reacted with the first and secondary antibodies, streptavidin-HRP, and detection solution according to the manufacture's instruction. The reaction was stopped using the stop solution (from the ELISA kits) and absorbance was read at $450 \mathrm{~nm}$ using a microplate reader (SH-9000Lab, Hitachi, Tokyo, Japan) [23].

\subsection{Statistical Analysis}

Statistical analysis was carried out similarly to our previous report [24]. All data, expressed as the mean $\pm \mathrm{SD}$, were analyzed statistically using GNU PSPP Statistical Analysis Software (version 0.8.2-gad9374; (https://www.gnu.org/software/pspp/) and EZAnalyze Excel-based tools (http:/ /www.ezanalyze.com/). A one-way analysis of the variance was followed by post hoc tests (including Tukey's test and Bonferroni correction). Statistical significance was considered when $p<0.05$. All experiments were repeated 3-5 time, independently.

\section{Results}

\subsection{HW Contains 100 Million Fine Hydrogen Bubbles}

The dissolved hydrogen escapes from the water very easily. We demonstrated that the half-life-time of dissolved hydrogen in regular hydrogen water was about $40 \mathrm{~min}$. However, if the hydrogen molecules were wrapped in nano-sized fine bubbles, the hydrogen did not easily escape. The NTA analysis showed that there were over 100 million fine bubbles in fresh HW. The average size of the bubbles was about $100 \mathrm{~nm}$ (Figure 1A-C). The number of bubbles decreased to approximately half after 8 months under the conditions in a screwcapped aluminum container with no air exchange. However, there was no significant difference between the 8,13 , and 15 month old HW. Surprisingly, after 8 years of storage time, $24 \%$ of the hydrogen bubbles still remained in the HW. These data suggest that hydrogen nano-bubbles in HW are very stable during storage. 


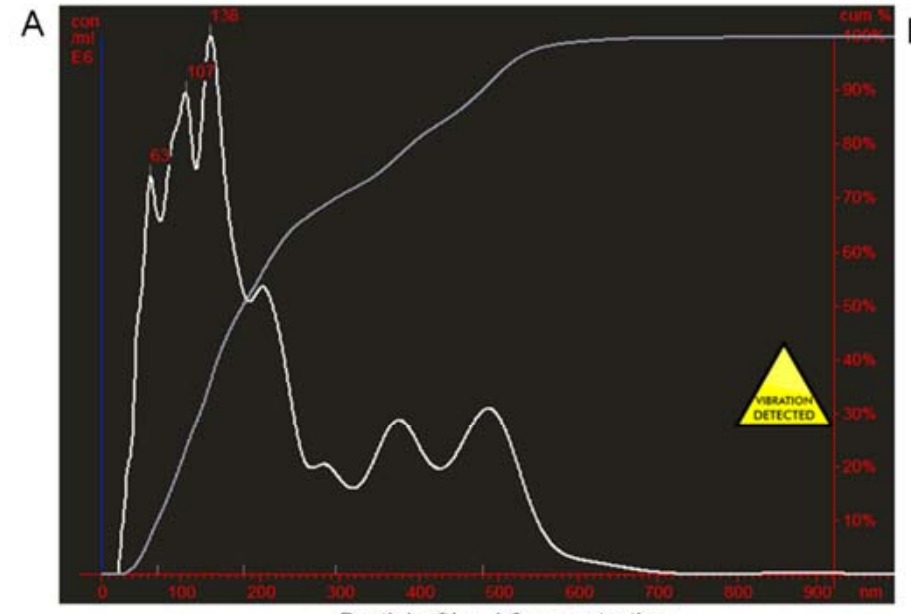

Particle Size / Concentration

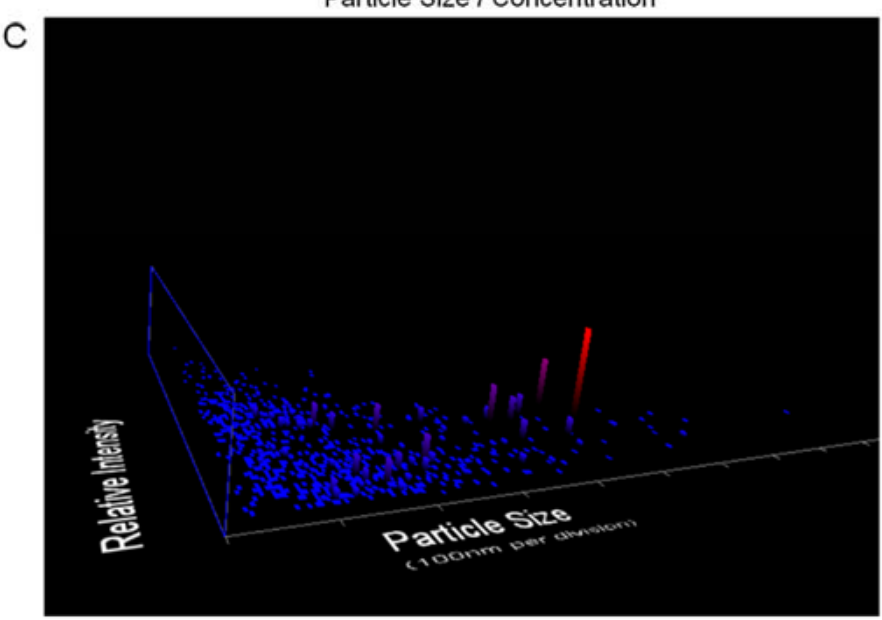

Particle Size / Relative Intensity 3D plot

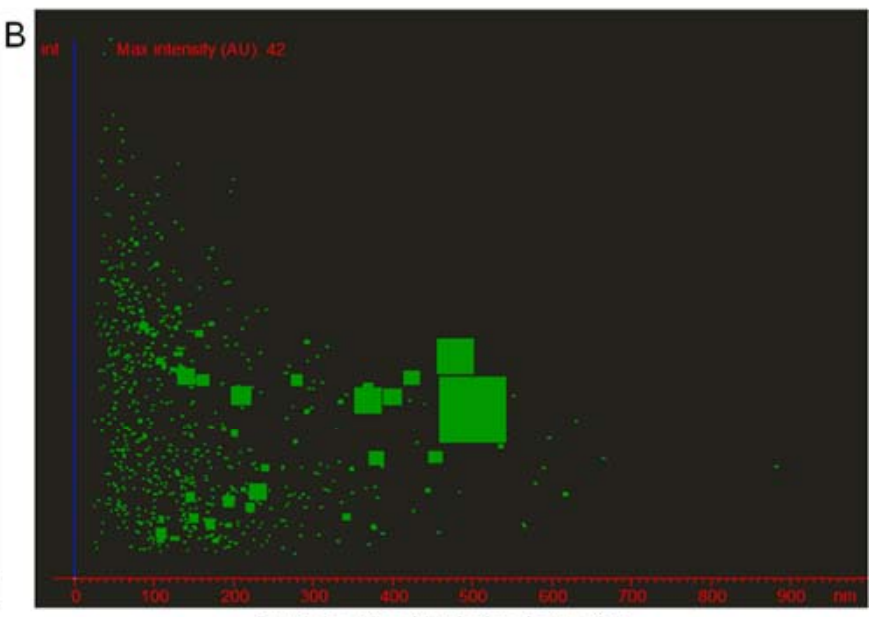

Particle Size / Relative Intensity

D

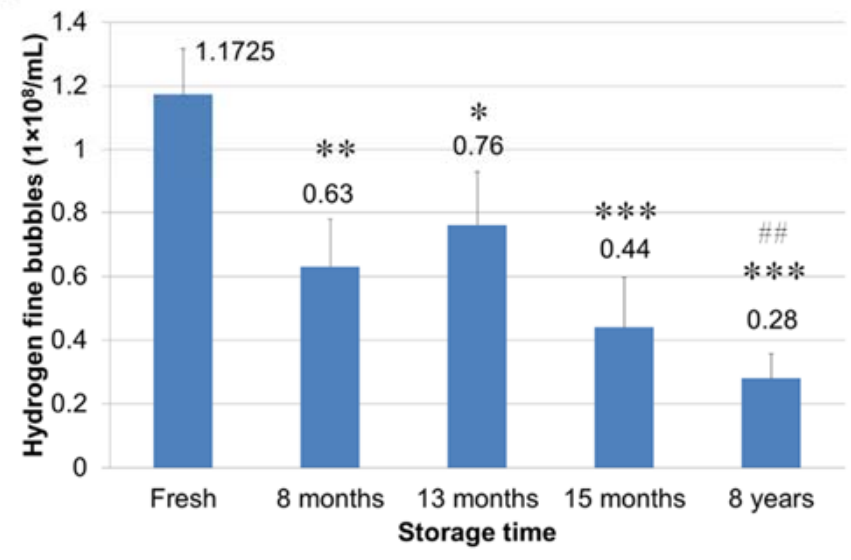

Figure 1. Concentration of hydrogen nano-bubbles in hydrogen nano-bubble water (HW). Nano-sized hydrogen bubbles in HW with different storage times were analyzed using Nanoparticle Tracking Analysis (NTA) software. Typical analysis results of particle size, distribution and number in HW are presented in (A-C). Numbers of hydrogen fine bubbles in $\mathrm{HW}$ samples were shown in (D). ${ }^{*} p<0.05,{ }^{* *} p<0.01,{ }^{* * *} p<0.001$ vs. fresh, \#\# $p<0.01$ vs. 8 months. Each bar represents the mean \pm SD of six independent experiments.

\subsection{Repressive Effects of $\mathrm{HW}$ on $\mathrm{H}_{2} \mathrm{O}_{2}$-Induced Cell Death in $\mathrm{HaCaT}$ Cells}

We tested the effects of $\mathrm{HW}$ on $\mathrm{H}_{2} \mathrm{O}_{2}$-induced cell death in $\mathrm{HaCaT}$ cells using two methods: live/dead staining and the PrestoBlue Assay. As shown in Figure $2 \mathrm{~B}, \mathrm{H}_{2} \mathrm{O}_{2}$ decreased cell viability in $\mathrm{HaCaT}$ cells in a concentration-dependent manner. $\mathrm{HW}$ showed significant protective effects in 0.25 and $0.5 \mathrm{mM} \mathrm{H}_{2} \mathrm{O}_{2}$-treated cells. Live/dead staining confirmed that $\mathrm{HW}$ reduced dead cells in $0.5 \mathrm{mM} \mathrm{H}_{2} \mathrm{O}_{2}$-treated cells. These data suggest that $\mathrm{HW}$ could protect $\mathrm{HaCaT}$ cells from $\mathrm{H}_{2} \mathrm{O}_{2}$-induced damage. 

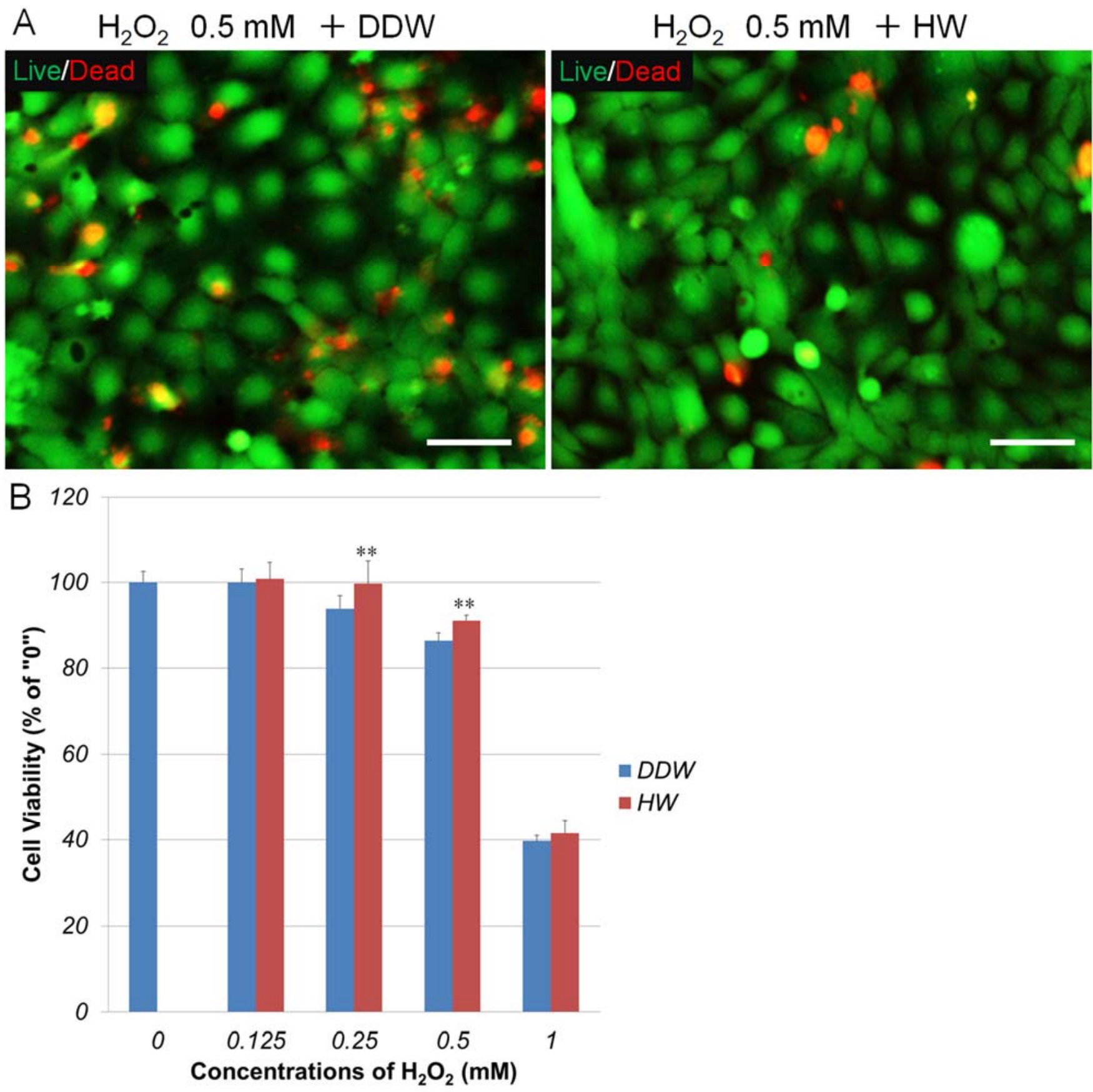

Figure 2. Repressive effects of HW on hydrogen peroxide-induced cell death in human keratinocytes HaCaT. HaCaT cells were pretreated with double-distilled water (DDW)- or HW-prepared medium for $2 \mathrm{~h}$. Cells were then exposed to $\mathrm{H}_{2} \mathrm{O}_{2}$ at different concentrations. After $48 \mathrm{~h}$, cell viability was measured by PrestoBlue Assay. (A) HaCaT cells were stained by Live/Dead staining. Green, live cells; red, dead cells. Scale bar $=50 \mu \mathrm{m}\left(\right.$ B) results of PrestoBlue Assay. ${ }^{* *} p<0.01$ vs. 0 (without $\mathrm{H}_{2} \mathrm{O}_{2}$ treatment). Each bar represents the mean $\pm \mathrm{SD}$ of three independent experiments.

\subsection{Repressive Effects of $\mathrm{HW}$ on $\mathrm{H}_{2} \mathrm{O}_{2}$-Induced Cellular ROS Generation in $\mathrm{HaCaT}$ Keratinocytes \\ As shown in Figure $3, \mathrm{H}_{2} \mathrm{O}_{2}$ treatment caused ROS generation in both the cytoplasm and nuclei in HaCaT cells. Cellular ROS production was increased in $\mathrm{H}_{2} \mathrm{O}_{2}$-concentration- dependent manner. When $\mathrm{HaCaT}$ cells were pre-cultivated in $\mathrm{HW}$-prepared medium for $2 \mathrm{~h}$, both the nuclei and cytoplasm ROS were significantly reduced, suggesting that HW could scavenge cellular ROS.}



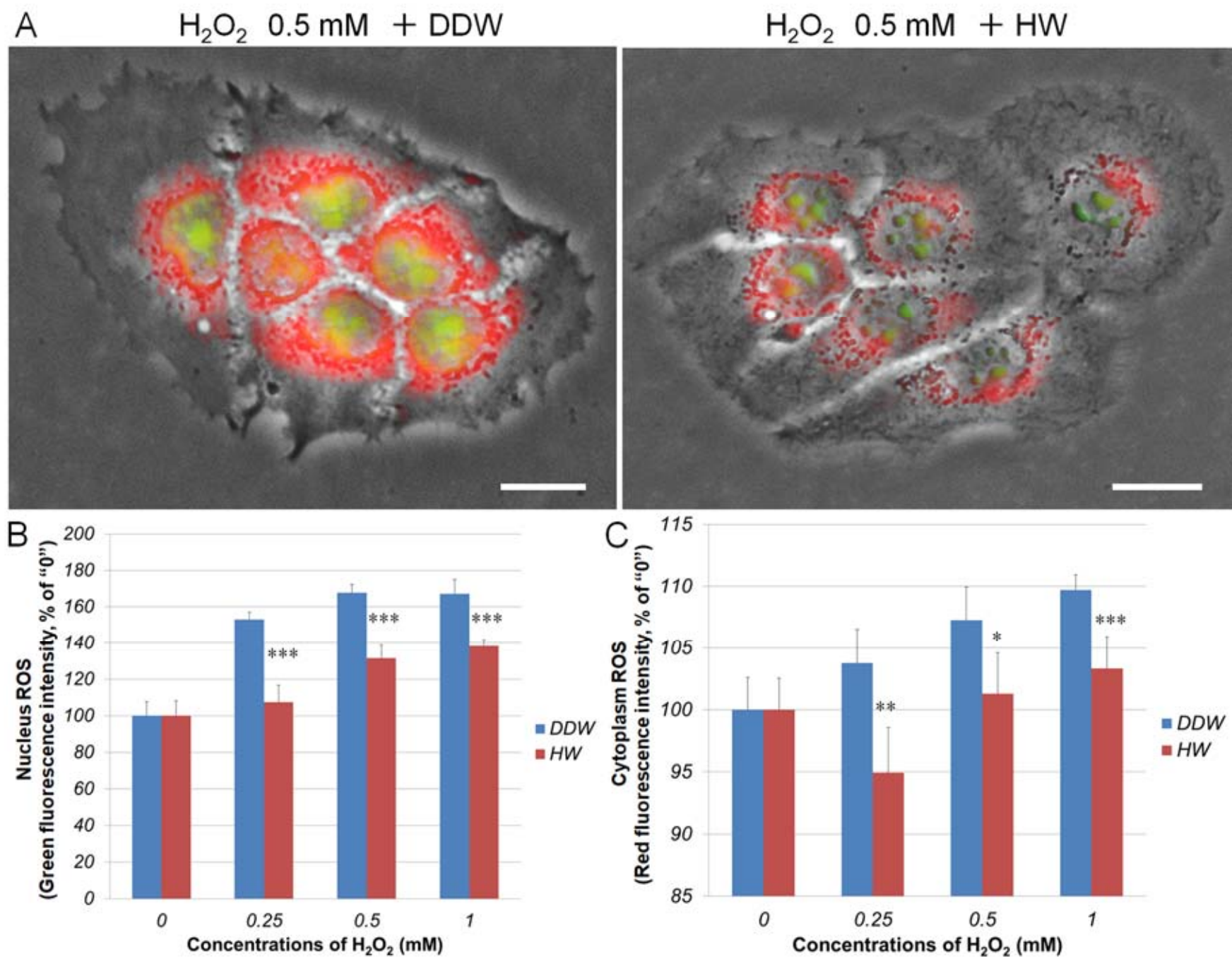

Figure 3. Repressive effects of HW on hydrogen peroxide-induced cellular ROS in human keratinocytes. HaCaT cells were pretreated with DDW- or HW-prepared medium for $2 \mathrm{~h}$. Cells were then exposed with $\mathrm{H}_{2} \mathrm{O}_{2}$ at different concentrations. At $24 \mathrm{~h}$ after $\mathrm{H}_{2} \mathrm{O}_{2}$-treatment, cellular ROS was detected with CellROX ${ }^{\circledR}$ green and orange dyes and observed with a fluorescence microscope. To quantitatively analyze the cellular ROS, green and red fluorescence in HaCaT cells were measured with the Tali image-based cytometer. (A) Typical images of CellROX ${ }^{\circledR}$ green and orange staining. Green, nucleus ROS; red, cytoplasm ROS. Scale bar $=10 \mu \mathrm{m}$. (B) and (C) HaCaT cells were detached from the culture substratum-surface by trypsin and followed with Tali-cytometric analysis to determine nucleus and cytoplasm ROS as described in materials and methods. ${ }^{*} p<0.05 ;{ }^{* *} p<0.01$; ${ }^{* * *} p<0.01$ vs. 0 (without $\mathrm{H}_{2} \mathrm{O}_{2}$ treatment). Each bar represents the mean $\pm \mathrm{SD}$ of three independent experiments.

3.4. Effect of $\mathrm{HW}$ on $\mathrm{H}_{2} \mathrm{O}_{2}$-Stimulated Adipogenesis in KSR-Differentiated OP9 Adipocytes and $3 D$ Subcutaneous Adipose Equivalents

In our previous study, we demonstrated that $\mathrm{H}_{2} \mathrm{O}_{2}$ at a low concentration $(5 \mu \mathrm{M})$ could stimulate adipogenesis in 3T3-L1 preadipocytes [20]. In this study, we found that $\mathrm{H}_{2} \mathrm{O}_{2}(5 \mu \mathrm{M})$ also significantly increased adipogenesis to $120 \%$ in KSR-differentiated OP9 adipocytes (Figure 4). Figure 4A shows that after being cultivated in KSR medium for 4 days, OP9 cells accumulated lipid droplets, especially in $\mathrm{H}_{2} \mathrm{O}_{2}$-treated cells. However, when OP9 cells were cultivated in HW-prepared KSR medium, the lipid accumulation significantly reduced. 


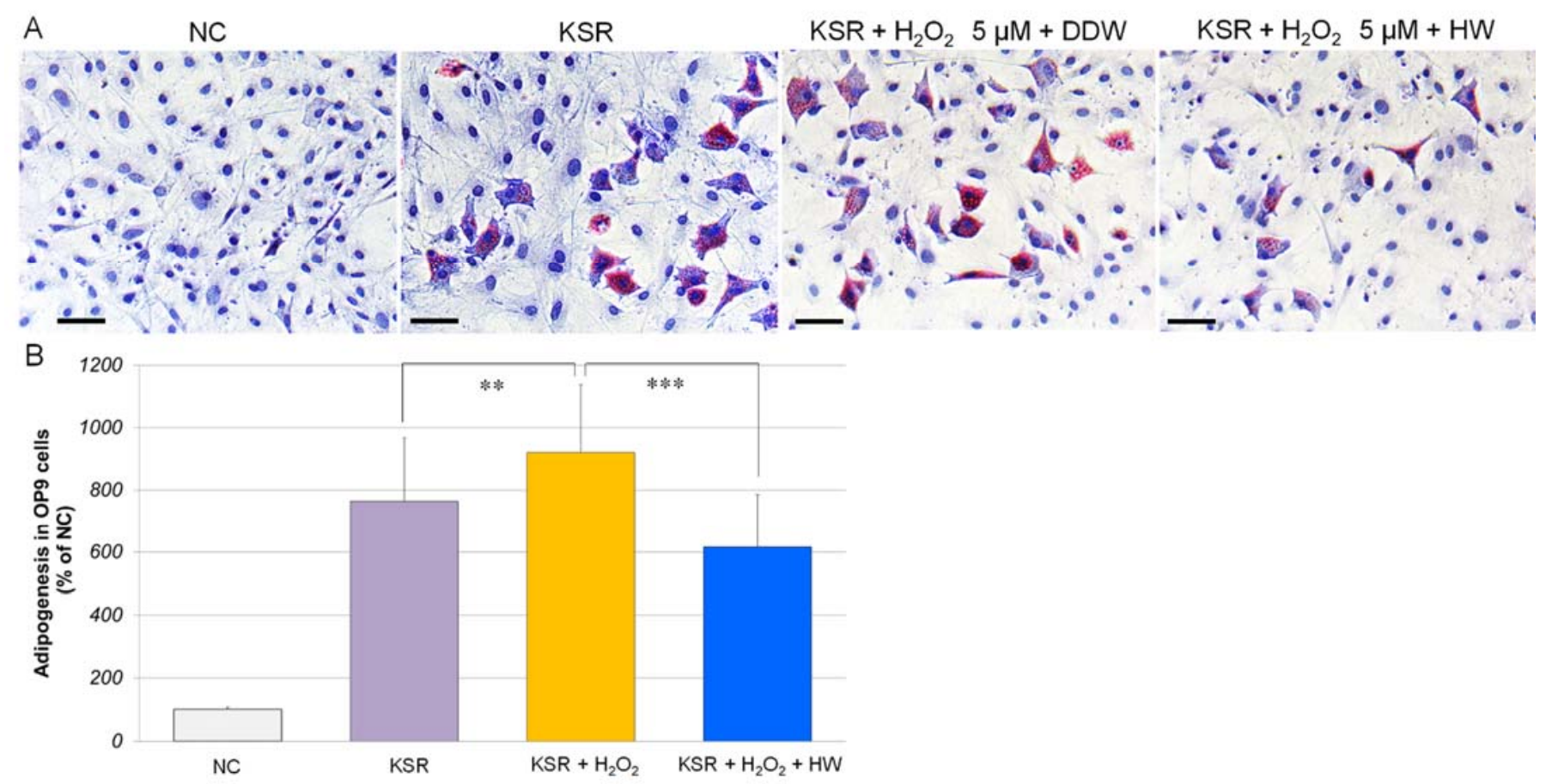

Figure 4. Repressive effects of HW on hydrogen-peroxide-stimulated adipogenesis in OP9 cells. OP9 preadipocytes (30,000 cells/well) were seeded into 24-well plates and grew to $100 \%$ confluence in the maintenance medium. Cells were then cultivated in DDW- or HW-prepared KSR medium with or without $\mathrm{H}_{2} \mathrm{O}_{2}$ for 4 days. The negative control (NC) cells were cultivated in the maintenance medium. At the end of cultivation, cells were fixed with $10 \%$ formalin. Cellular lipid droplets were stained with Oil Red O dye. The intracellular dye was extracted and transferred to a 96-well plate, and quantified in a microplate reader at $520 \mathrm{~nm}$. (A) Typical images of Oil Red O staining. Blue, nuclei; red, lipid droplets. Scale bar $=25 \mu \mathrm{m}$. (B) Data are expressed as a percentage of the negative control, and each concentration point and bar represent the mean \pm SD of five independent experiments. ${ }^{* *} p<0.01 ; * * * 0.001$.

We further examined whether $\mathrm{HW}$ had similar effects on $\mathrm{H}_{2} \mathrm{O}_{2}$-stimulated adipogenesis in 3D subcutaneous adipose equivalents. Figure 5 shows that with $\mathrm{H}_{2} \mathrm{O}_{2}(5 \mu \mathrm{M})$ treatment, there were about $145 \%$ more lipid droplets accumulated in the subcutis of KSRdifferentiated adipose equivalents. When the equivalents were cultivated in HW-prepared KSR medium, the lipid accumulation was significantly reduced to $110 \%$.

These data suggest that $\mathrm{HW}$ could suppress $\mathrm{H}_{2} \mathrm{O}_{2}$ adipogenesis in both OP9 adipocytes and $3 \mathrm{D}$ adipose equivalents. 

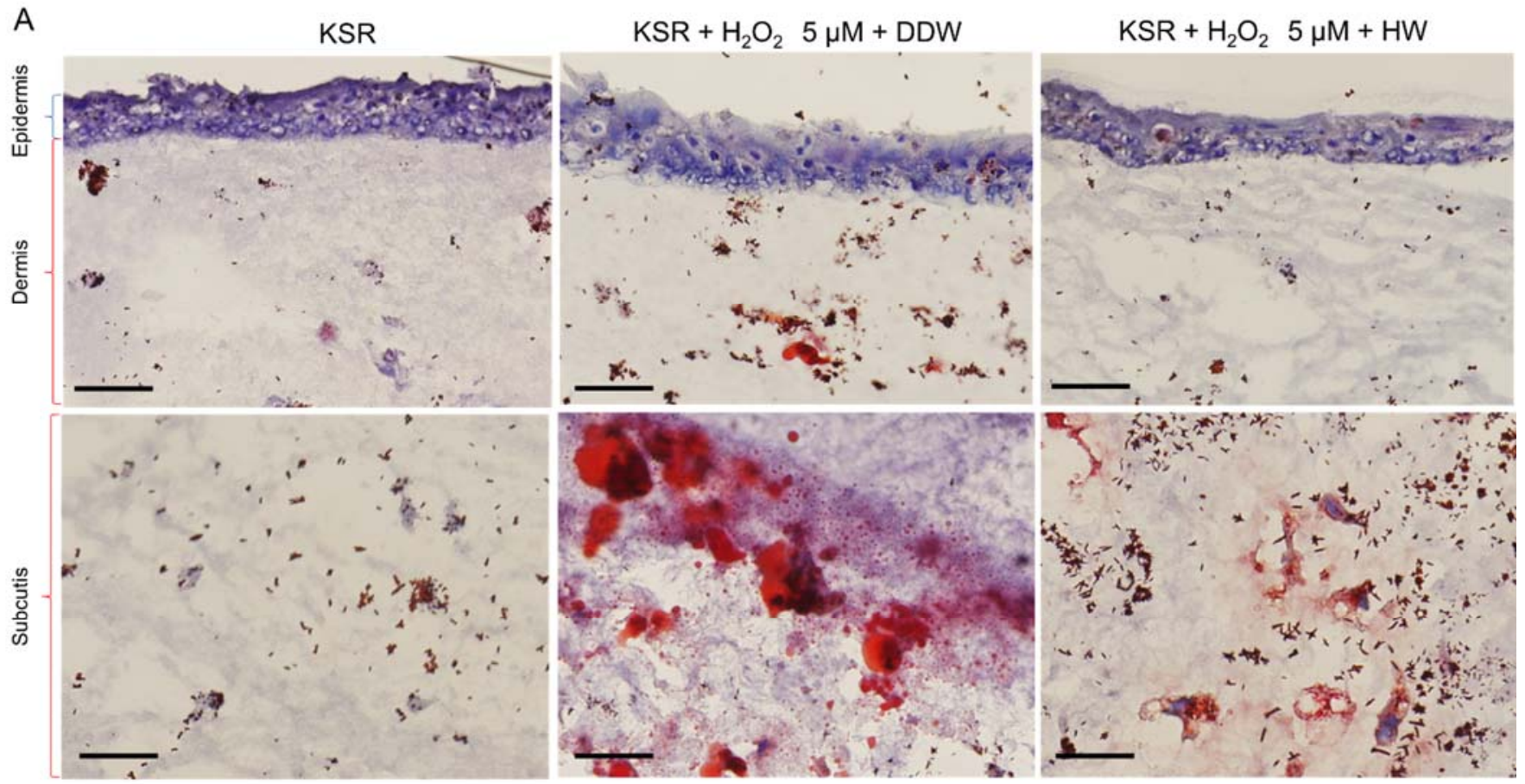

B

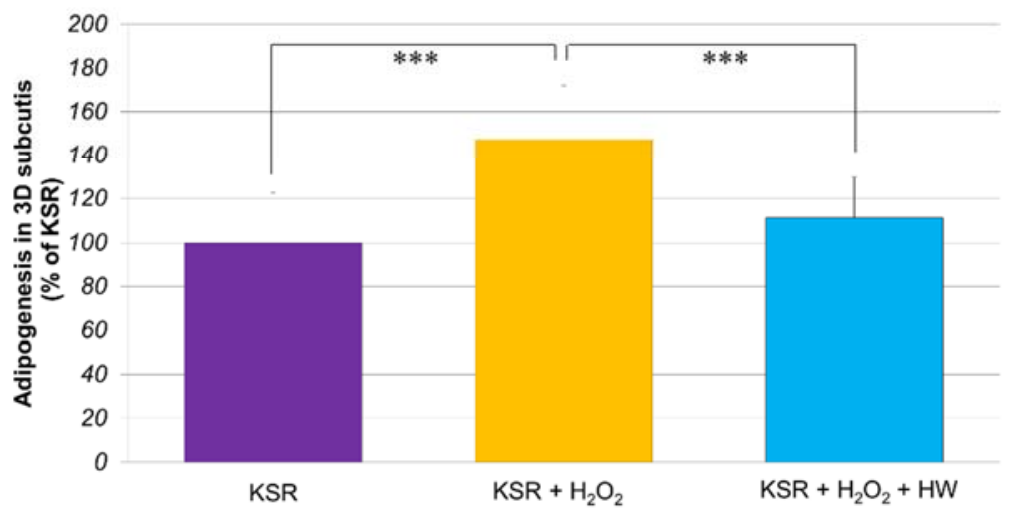

Figure 5. Repressive effects of HW on hydrogen peroxide-stimulated adipogenesis in 3D subcutaneous adipose equivalents. 3D equivalents were constructed as described in Materials and Methods. The 3D equivalents were cultivated in DDWor HW-prepared KSR medium with or without $\mathrm{H}_{2} \mathrm{O}_{2}(5 \mu \mathrm{M})$ for 4 days. At the end of cultivation, the tissue was fixed with $10 \%$ formalin and subjected to the frozen section. The lipid droplets were stained with Oil Red O dye. The images were taken by a microscope and analyzed with ImageJ software. (A) Typical images of Oil Red O staining. Blue, nuclei; red, lipid droplets. The scale bars indicate $100 \mu \mathrm{m}$ in the upper panel and $50 \mu \mathrm{m}$ in the lower panel, respectively; (B) data are expressed as a percent of KSR, and each concentration point and bar represent the mean \pm SD of five independent experiments. ${ }^{* * *} p<0.001$.

\subsection{Effect of HW on PMA-Induced ROS Generation, Adipogenesis, and IL-6 Secretion in} KSR-Differentiated OP9 Adipocytes

PMA was used as a NADPH oxidase activator, which induces endogenous superoxide anion and hydrogen peroxide in macrophages [25]. PMA also induces ROS generation and oxidative stress in human leukemia cell lines: THP-1 and U937 cells [26,27]. Both THP-1 and U937 cells can be differentiated into macrophage-like cells after being treated with PMA [28,29]. In this study, we demonstrated for the first time that PMA could increase lipid accumulation in KSR-differentiated OP9 cells. As shown in Figure 6, after being cultivated in KSR medium with PMA (10 ng/mL) for 4 days, cellular lipid droplets increased by $180 \%$ compared with the cells treated with KSR alone. At the same time, the ROS level of both cytoplasm and nuclei in OP9 cells was also markedly increased. When OP9 cells were cultivated in HW-prepared KSR medium with PMA for 4 days, cellular lipid droplets, 
nuclei, and cytoplasm ROS were significantly reduced, suggesting that HW was able to inhibit PMA-induced intracellular ROS and lipid accumulation.

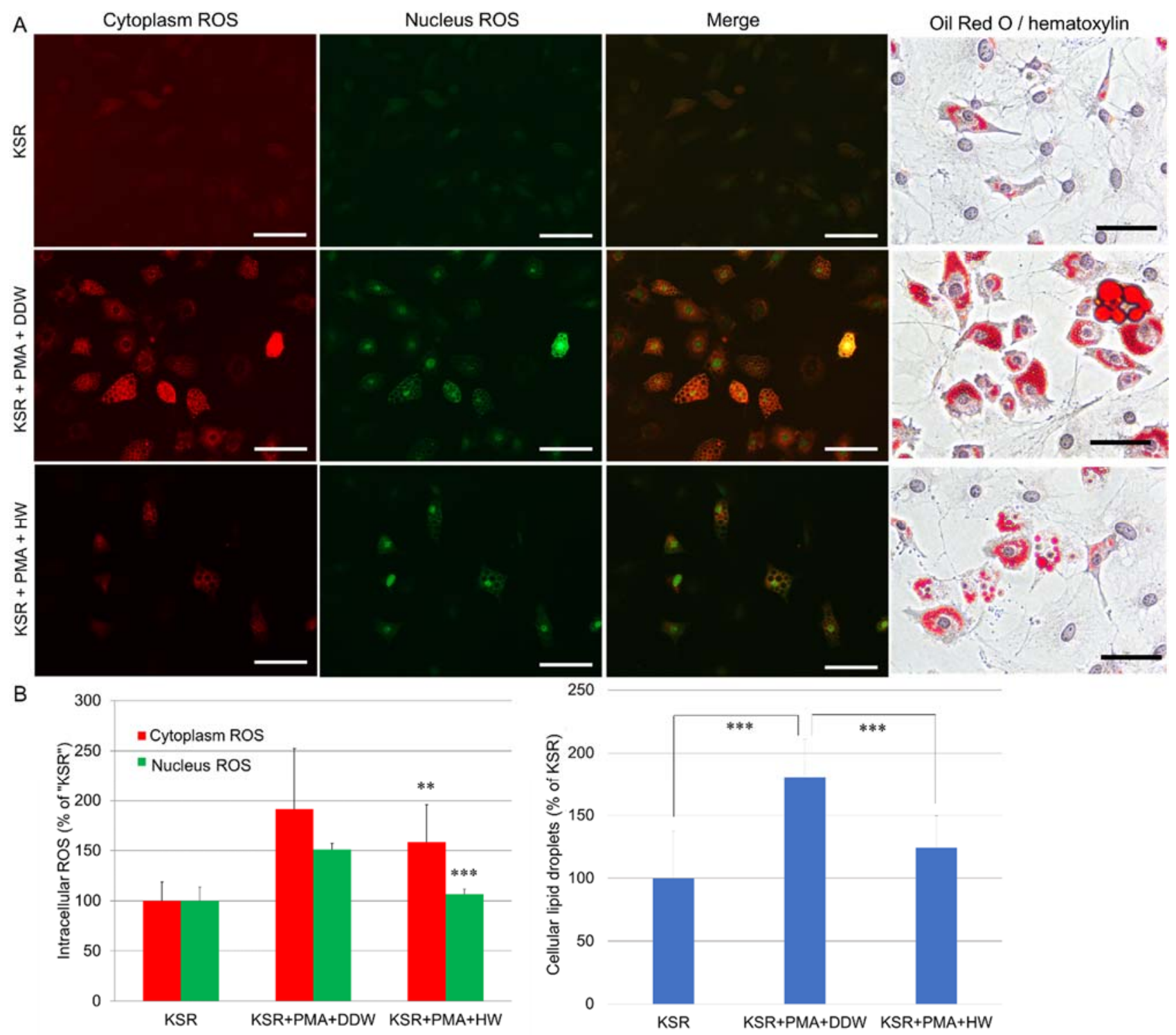

Figure 6. Repressive effects of HW on phorbol 12-myristate 13-acetate (PMA)-induced intracellular ROS and lipid accumulation in OP9 adipocytes. (A) OP9 preadipocytes (30,000 cells/well) were seeded into 24 -well plates and grew up to $100 \%$ confluence in the maintenance medium. Cells were then cultivated in DDW- or HW-prepared KSR medium with or without PMA of $10 \mathrm{ng} / \mathrm{mL}$ for 4 days. The NC cells were cultivated in the maintenance medium. At the end of cultivation, cellular ROS were detected with CellROX ${ }^{\circledR}$ green and orange dyes and observed with a fluorescence microscope. To quantitatively analyze the cellular ROS, green and red fluorescence in OP9 cells were measured with the Tali image-based cytometer. For Oil Red O staining, OP9 cells were prepared similar to what we described in Figure 4. (A) Left panel:typical images of CellROX ${ }^{\circledR}$ green and orange staining. Green, nucleus ROS; red, cytoplasm ROS. Scale bar $=25 \mu \mathrm{m}$. Right panel: typical images of Oil Red O staining. Scale bar $=25 \mu \mathrm{m}$. (B) Left panel: OP9 cells were detached from the culture substratum-surface by trypsin and followed by Tali-cytometric analysis as described in materials and methods. ${ }^{* *} p<0.01 ;{ }^{* * *} p<0.01$ vs. KSR+PMA+DDW. Right panel: after Oil Red O staining, the intracellular dye was extracted and transferred to a 96-well plate and quantified in a microplate reader at $520 \mathrm{~nm}$. ${ }^{* * *} p<0.001 \mathrm{vs.} \mathrm{KSR+PMA+DDW}$. Data are expressed as percentage of the negative control, and each concentration point and bar represent the mean $\pm \mathrm{SD}$ of five independent experiments.

The inflammatory cytokine IL-6 is known to play an essential role in the inflammation of adipose tissue and insulin resistance [15]. Figure 7 shows that during KSR-initiated 
differentiation OP9 adipocytes secreted 1.8 times more IL- 6 than the negative control. PMAtreatment further increased the level of IL-6 by $270 \%$ of KSR-differentiated adipocytes, suggesting that PMA could markedly stimulate the secretion of IL-6 in OP9 adipocytes. However, when OP9 cells were cultivated in HW-prepared KSR medium with PMA for 4 days, IL-6 were significantly decreased, suggesting that HW was able to inhibit PMAinduced IL-6 secretion.

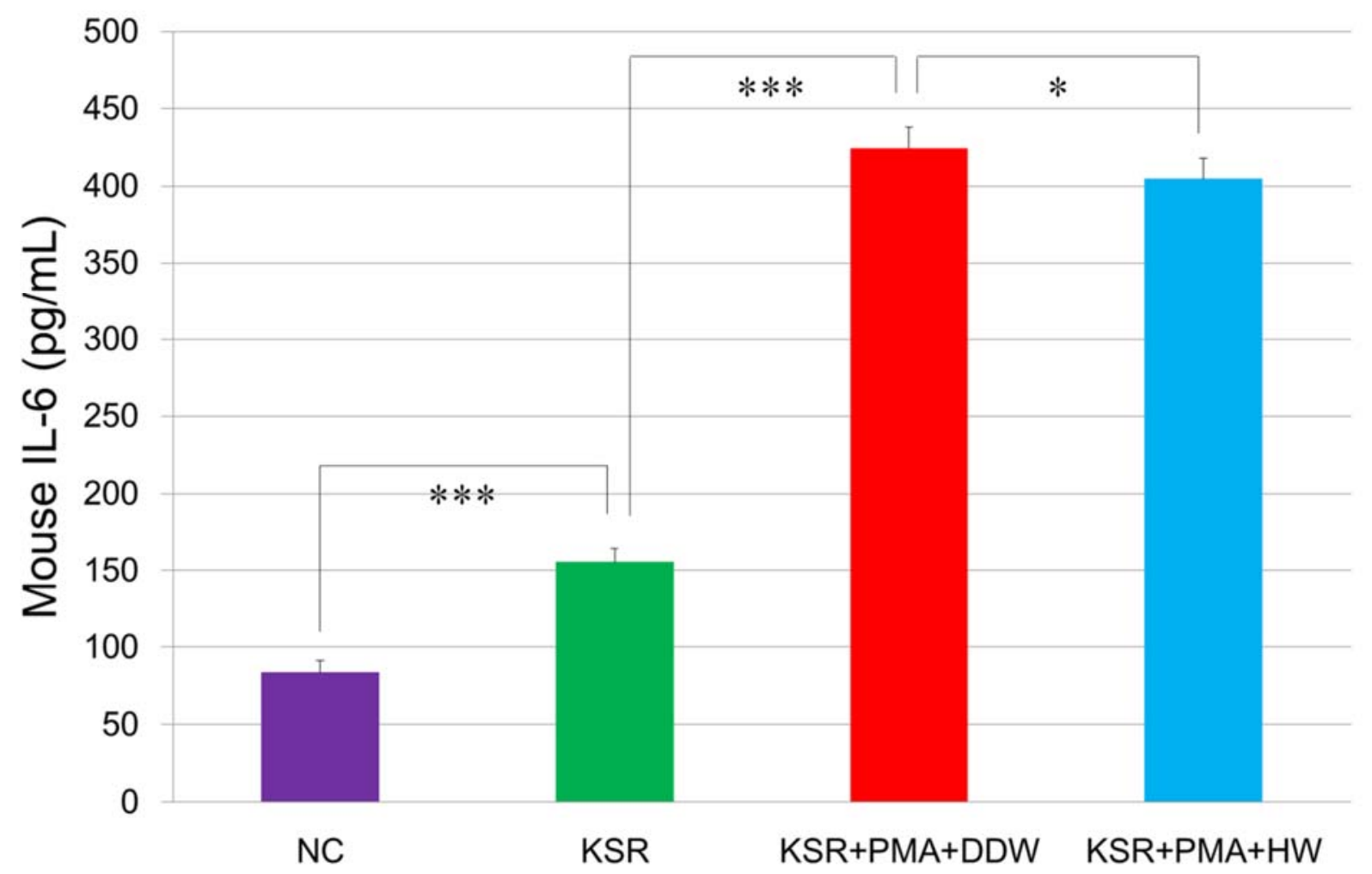

Figure 7. Repressive effects of HW on PMA-increased IL-6 secretion in OP9 adipocytes. OP9 preadipocytes (30,000 cells/well) were seeded into 24 -well plates and grew to $100 \%$ confluence in the maintenance medium. Cells were then cultivated in DDW- or HW-prepared KSR medium with or without PMA of $10 \mathrm{ng} / \mathrm{mL}$ for 4 days. The NC cells were cultivated in the maintenance medium. At the end of cultivation, concentrations of IL- 6 in cell culture supernatant were measured by ELISA as described in Materials and Methods. ${ }^{*} p<0.05 ;{ }^{* *} p<0.001$. Each bar represents the mean \pm SD of three independent experiments.

\section{Discussion}

Hydrogen molecules can easily permeate cellular membranes and reduce oxidative stress [30]. Recently, a randomized, double-blind, controlled clinical trial reported that hydrogen-rich water could increase serum antioxidant capacity and reduce inflammatory responses in healthy adults [31]. However, dissolved hydrogen molecules escape very easily from the solution. Our previous study showed that the half-time of dissolved hydrogen in magnesium stick-prepared hydrogen-rich water was only $40 \mathrm{~min}$ [19]. Fine bubble technology is a newly established technology that has been developed in medical, pharmaceutical, and dental applications in Japan. Fine bubbles in liquids exhibit excellent stability and permeability. In the present study, we demonstrated that fine hydrogen nanobubbles are very stable in water. The number of hydrogen nano-bubbles remained in HW for a long period of storage time. Even after 8 years of storage, $24 \%$ of the bubbles remained.

Our cellular experiments showed that $\mathrm{H}_{2} \mathrm{O}_{2}$ at higher concentrations $(0.25-1 \mathrm{mM})$ severely damaged $\mathrm{HaCaT}$ keratinocytes, resulting in cell death and the production of ROS. $\mathrm{HW}$ could inhibit $\mathrm{H}_{2} \mathrm{O}_{2}$-induced ROS generation; therefore, prevent $\mathrm{H}_{2} \mathrm{O}_{2}$-caused cell death in $\mathrm{HaCaT}$ cells. As one of the harmful ROS, $\mathrm{H}_{2} \mathrm{O}_{2}$ facilitates adipocyte differen- 
tiation [32]. It was reported that $\mathrm{H}_{2} \mathrm{O}_{2}$ at a concentration as low as $5 \mu \mathrm{M}$ did not show cytotoxicity [33]. Our data showed that $\mathrm{H}_{2} \mathrm{O}_{2}$ at $5 \mu \mathrm{M}$ could increase the cellular lipid accumulation to $120 \%$ of KSR-differentiated OP9 adipocytes. It was reported that subcutaneous adipose tissue (SAT) releases IL-6 in vivo [34]. Expanded SAT increases the metabolic and cardiovascular risk in some populations [35]. Here, we reconstructed 3D subcutaneous adipose equivalents using $\mathrm{HaCaT}$ keratinocytes and OP9 preadipocytes. As shown in Figure 5, after being cultivated in KSR medium for 2-4 weeks, HaCaT cells formed an epidermis with multilayers. Under the epidermis, OP9 preadipocytes formed dermis with only a few lipid droplets. Beneath the dermis, OP9 cells differentiated into adipocytes accompanying massive lipid accumulation, especially with $\mathrm{H}_{2} \mathrm{O}_{2}$ stimulation, indicating the formation of subcutis. HW significantly inhibited $\mathrm{H}_{2} \mathrm{O}_{2}$-induced adipogenesis in both KSR-differentiated OP9 adipocytes and 3D subcutaneous adipose equivalents.

The ROS initiator, PMA, is also known as a potent tumor promoter that activates the signal transduction enzyme protein kinase $\mathrm{C}$ (PKC) and differentiates cancerous lymphocytes, such as THP-1 cells [36,37]. Since PKC signaling activates inflammatory responses, PMA is often used as a potent inducer of inflammation in animal models $[38,39]$. In our previous study, we found that $10 \mathrm{ng} / \mathrm{mL}$ of PMA could efficiently induce the differentiation of THP- 1 cells, as did other researchers [40-42]. We also discovered that a longer duration of treatment (more than 4 days) with PMA can promote maturation of THP-1 macrophages (data not shown). In this study, we discovered for the first time that PMA $(10 \mathrm{ng} / \mathrm{mL}$, 4 days) could enhance adipogenesis by $180 \%$ and IL- 6 secretion as abundant as $270 \%$ of KSR-differentiated OP9 adipocytes. PMA also increased cellular ROS generation in OP9 adipocytes. This discovery clarifies the relationship among inflammation, adipogenesis, and oxidative stress in obesity at the cellular level in vitro. PMA-stimulated OP9 adipocytes can be applied as a new cell model for metabolic disorders. HW significantly suppressed PMA-induced lipid accumulation, ROS generation, and IL-6 secretion in OP9 cells, suggesting it might prevent the development of metabolic disorders. Since oxidative stress and inflammation play essential roles in many chronic metabolic diseases and hydrogen water is known for lacking adverse effects [30], the use of hydrogen water can be applied for the prevention of these diseases. However, more randomized, double-blind, controlled clinical trials and well-designed long-term cohort studies need to be performed in the future.

\section{Conclusions}

In conclusion, $\mathrm{HW}$ exhibits excellent stability and can protect $\mathrm{HaCaT}$ cells from harmful $\mathrm{H}_{2} \mathrm{O}_{2}$-induced injuries. HW significantly suppressed $\mathrm{H}_{2} \mathrm{O}_{2}$ - or PMA-enhanced adipogenesis, ROS generation, and IL-6 secretion in OP9 adipocytes and 3D subcutaneous adipose tissue. Therefore, HW can be applied as a potential health care candidate for preventing metabolic disorders.

Author Contributions: Conceptualization, L.X. and N.M.; methodology, L.X. and N.M; software, L.X.; validation, L.X. and N.M.; formal analysis, L.X.; investigation, L.X.; resources, L.X. and N.M.; data curation, L.X.; writing-original draft preparation, L.X.; writing-review and editing, L.X. and N.M.; visualization, L.X.; supervision, L.X. and N.M.; project administration, L.X. and N.M.; funding acquisition, L.X. Both authors have read and agreed to the published version of the manuscript. All authors have read and agreed to the published version of the manuscript.

Funding: This research was funded in part by a Grant-in-Aid for AntiAging Scientific Research \#1517 by Japanese Center for AntiAging MedSciences, Hiroshima, Japan to L.X.

Institutional Review Board Statement: Not applicable.

Informed Consent Statement: Not applicable.

Data Availability Statement: The data presented in this study are available within the article. There are no databases associated with this manuscript.

Acknowledgments: The authors also appreciate Nathaniel Green's proofreading.

Conflicts of Interest: The authors declare no conflict of interest. 


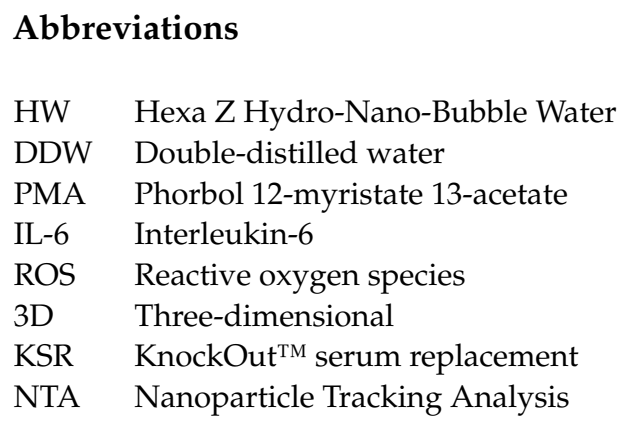

\section{References}

1. Hotamisligil, G. Inflammation and metabolic disorders. Nature 2006, 444, 860-867. [CrossRef]

2. Després, J.P.; Lemieux, I. Abdominal obesity and metabolic syndrome. Nature 2006, 444, 881-887. [CrossRef] [PubMed]

3. Lind, L.; Sundström, J.; Ärnlöv, J.; Risérus, U.; Lampa, E. A longitudinal study over 40 years to study the metabolic syndrome as a risk factor for cardiovascular diseases. Sci. Rep. 2021, 11, 2978. [CrossRef] [PubMed]

4. van Herpen, N.A.; Schrauwen-Hinderling, V.B. Lipid accumulation in non-adipose tissue and lipotoxicity. Physiol. Behav. 2008, 94, 231-241. [CrossRef]

5. $\quad$ Furukawa, S.; Fujita, T.; Shimabukuro, M.; Iwaki, M.; Yamada, Y.; Nakajima, Y.; Nakayama, O.; Makishima, M.; Matsuda, M.; Shimomura, I. Increased oxidative stress in obesity and its impact on metabolic syndrome. J. Clin. Investig. 2004, 114, 1752-1761. [CrossRef] [PubMed]

6. Masschelin, P.M.; Cox, A.R.; Chernis, N.; Hartig, S.M. The Impact of Oxidative Stress on Adipose Tissue Energy Balance. Front. Physiol. 2020, 10, 1638. [CrossRef]

7. Birben, E.; Sahiner, U.M.; Sackesen, C.; Erzurum, S.; Kalayci, O. Oxidative stress and antioxidant defense. World Allergy Organ. J. 2012, 5, 9-19. [CrossRef]

8. Lushchak, V.I. Free radicals, reactive oxygen species, oxidative stress and its classification. Chem. Biol. Interact. 2014, 224, 164-175. [CrossRef] [PubMed]

9. Sauer, H.; Wartenberg, M.; Hescheler, J. Reactive oxygen species as intracellular messengers during cell growth and differentiation Cell Physiol. Biochem. 2001, 11, 173-186. [CrossRef]

10. Youn, J.Y.; Siu, K.L.; Lob, H.E.; Itani, H.; Harrison, D.G.; Cai, H. Role of vascular oxidative stress in obesity and metabolic syndrome. Diabetes 2014, 63, 2344-2355. [CrossRef]

11. Aroor, A.R.; DeMarco, V.G. Oxidative stress and obesity: The chicken or the egg? Diabetes 2014, 63, 2216-2218. [CrossRef]

12. Lara-Castro, C.; Garvey, W.T. Intracellular lipid accumulation in liver and muscle and the insulin resistance syndrome. Endocrinol. Metab. Clin. N. Am. 2008, 37, 841-856. [CrossRef]

13. Xu, H.; Barnes, G.T.; Yang, Q.; Tan, G.; Yang, D.; Chou, C.J.; Sole, J.; Nichols, A.; Ross, J.S.; Tartaglia, L.A.; et al. Chronic inflammation in fat plays a crucial role in the development of obesity-related insulin resistance. J. Clin. Investig. 2003, 112, 1821-1830. [CrossRef]

14. Han, C.Y. Roles of Reactive Oxygen Species on Insulin Resistance in Adipose Tissue. Diabetes Metab. J. 2016, 40, 272-279. [CrossRef] [PubMed]

15. Han, M.S.; White, A.; Perry, R.J.; Camporez, J.P.; Hidalgo, J.; Shulman, G.I.; Davis, R.J. Regulation of adipose tissue inflammation by interleukin 6. Proc. Natl. Acad. Sci. USA 2020, 117, 2751-2760. [CrossRef]

16. Ohta, S. Molecular hydrogen as a preventive and therapeutic medical gas: Initiation, development and potential of hydrogen medicine. Pharmacol. Ther. 2014, 144, 1-11. [CrossRef]

17. Nakamura, M.; Ito, M. Coadsorption of water dimer and ring-hexamer clusters on $\mathrm{M}(111)(\mathrm{M}=\mathrm{Cu}, \mathrm{Ni}, \mathrm{Pt})$ and $\mathrm{Ru}(001)$ surfaces at $25 \mathrm{~K}$ as studied by infrared reflection absorption spectroscopy. Chem. Phys. Lett. 2005, 404, 346-350. [CrossRef]

18. Boukamp, P.; Petrussevska, R.T.; Breitkreutz, D.; Hornung, J.; Markham, A.; Fusenig, N.E. Normal keratinization in a spontaneously immortalized aneuploid human keratinocyte cell line. J. Cell Biol. 1988, 106, 761-771. [CrossRef] [PubMed]

19. Xiao, L.; Miwa, N. Hydrogen-rich water achieves cytoprotection from oxidative stress injury in human gingival fibroblasts in culture or 3D-tissue equivalents, and wound-healing promotion, together with ROS-scavenging and relief from glutathione diminishment. Hum. Cell 2017, 30, 72-87. [CrossRef] [PubMed]

20. Xiao, L.; Aoshima, H.; Saitoh, Y.; Miwa, N. Highly hydroxylated fullerene localizes at the cytoskeleton and inhibits oxidative stress in adipocytes and a subcutaneous adipose-tissue equivalent. Free Radic. Biol. Med. 2011, 51, 1376-1389. [CrossRef] [PubMed]

21. Xiao, L.; Mochizuki, M.; Nakahara, T.; Miwa, N. Hydrogen-Generating Silica Material Prevents UVA-ray-Induced Cellular Oxidative Stress, Cell Death, Collagen Loss and Melanogenesis in Human Cells and 3D Skin Equivalents. Antioxidants 2021, 10, 76. [CrossRef] [PubMed]

22. Xiao, L.; Aoshima, H.; Saitoh, Y.; Miwa, N. The effect of squalane-dissolved fullerene-C60 on adipogenesis-accompanied oxidative stress and macrophage activation in a preadipocyte-monocyte co-culture system. Biomaterials 2010, 31, 5976-5985. [CrossRef] 
23. Xiao, L.; Liao, F.; Ide, R.; Horie, T.; Fan, Y.; Saiki, C.; Miwa, N. Enzyme-digested Colla Corii Asini (E'jiao) prevents hydrogen peroxide-induced cell death and accelerates amyloid beta clearance in neuronal-like PC12 cells. Neural Regen Res. 2020, 15, 2270-2272. [CrossRef]

24. Xiao, L.; Sakagami, H.; Miwa, N. A New Method for Testing Filtration Efficiency of Mask Materials Under Sneeze-like Pressure. In Vivo 2020, 34, 1637-1644. [CrossRef]

25. Kuwabara, W.M.; Zhang, L.; Schuiki, I.; Curi, R.; Volchuk, A.; Alba-Loureiro, T.C. NADPH oxidase-dependent production of reactive oxygen species induces endoplasmatic reticulum stress in neutrophil-like HL60 cells. PLoS ONE 2015, 10, e0116410. [CrossRef]

26. Kasai, S.; Shiku, H.; Torisawa, Y.; Noda, H.; Yoshitake, J.; Shiraishi, T.; Yasukawa, T.; Watanabe, T.; Matsue, T.; Yoshimura, T. Real-time monitoring of reactive oxygen species production during differentiation of human monocytic cell lines (THP-1). Anal. Chim. Acta 2005, 549, 14-19. [CrossRef]

27. Prasad, A.; Sedlářová, M.; Balukova, A.; Ovsii, A.; Rác, M.; Křupka, M.; Kasai, S.; Pospíšil, P. Reactive Oxygen Species Imaging in U937 Cells. Front. Physiol. 2020, 11, 552569. [CrossRef] [PubMed]

28. Tsuchiya, S.; Kobayashi, Y.; Goto, Y.; Okumura, H.; Nakae, S.; Konno, T.; Tada, K. Induction of maturation in cultured human monocytic leukemia cells by a phorbol diester. Cancer Res. 1982, 42, 1530-1536.

29. Stoppelli, M.P.; Corti, A.; Soffientini, A.; Cassani, G.; Blasi, F.; Assoian, R.K. Differentiation-enhanced binding of the aminoterminal fragment of human urokinase plasminogen activator to a specific receptor on U937 monocytes. Proc. Natl. Acad. Sci. USA 1985, 82, 4939-4943. [CrossRef]

30. Iuchi, K.; Imoto, A.; Kamimura, N.; Nishimaki, K.; Ichimiya, H.; Yokota, T.; Ohta, S. Molecular hydrogen regulates gene expression by modifying the free radical chain reaction-dependent generation of oxidized phospholipid mediators. Sci. Rep. 2016, 6, 18971. [CrossRef]

31. Sim, M.; Kim, C.S.; Shon, W.J.; Lee, Y.K.; Choi, E.Y.; Shin, D.M. Hydrogen-rich water reduces inflammatory responses and prevents apoptosis of peripheral blood cells in healthy adults: A randomized, double-blind, controlled trial. Sci. Rep. 2020, 10, 12130. [CrossRef]

32. Lee, H.; Lee, Y.J.; Choi, H.; Ko, E.H.; Kim, J.W. Reactive oxygen species facilitate adipocyte differentiation by accelerating mitotic clonal expansion. J. Biol. Chem. 2009, 284, 10601-10609. [CrossRef]

33. Huang, B.K.; Sikes, H.D. Quantifying intracellular hydrogen peroxide perturbations in terms of concentration. Redox Biol. 2014, 2, 955-962. [CrossRef]

34. Mohamed-Ali, V.; Goodrick, S.; Rawesh, A.; Katz, D.R.; Miles, J.M.; Yudkin, J.S.; Klein, S.; Coppack, S.W. Subcutaneous adipose tissue releases interleukin-6, but not tumor necrosis factor-alpha, in vivo. J. Clin. Endocrinol. Metab. 1997, 82, 4196-4200. [CrossRef]

35. Porter, S.A.; Massaro, J.M.; Hoffmann, U.; Vasan, R.S.; O’Donnel, C.J.; Fox, C.S. Abdominal subcutaneous adipose tissue: A protective fat depot? Diabetes Care 2009, 32, 1068-1075. [CrossRef]

36. Auwerx, J. The human leukemia cell line, THP-1: A multifacetted model for the study of monocyte-macrophage differentiation. Experientia 1991, 47, 22-31. [CrossRef] [PubMed]

37. Schwende, H.; Fitzke, E.; Ambs, P.; Dieter, P. Differences in the state of differentiation of THP-1 cells induced by phorbol ester and 1,25-dihydroxyvitamin D3. J. Leukoc. Biol. 1996, 59, 555-561. [CrossRef] [PubMed]

38. Zhang, G.; Liu, X.; Wang, C.; Qu, L.; Deng, J.; Wang, H.; Qin, Z. Resolution of PMA-induced skin inflammation involves interaction of IFN- $\gamma$ and ALOX15. Mediat. Inflamm. 2013, 2013, 930124. [CrossRef]

39. Wu, B.C.; Skovbakke, S.L.; Masoudi, H.; Hancock, R.E.W.; Franzyk, H. In vivo Anti-inflammatory Activity of Lipidated Peptidomimetics Pam-(Lys- $\beta$ Nspe)6-NH2 and Lau-(Lys- $\beta$ Nspe)6-NH2 Against PMA-Induced Acute Inflammation. Front. Immunol. 2020, 11, 2102. [CrossRef] [PubMed]

40. Xiao, L.; Okamura, H.; Kumazawa, Y. Three-dimensional Inflammatory Human Tissue Equivalents of Gingiva. J. Vis. Exp. 2018, 134, 57157. [CrossRef] [PubMed]

41. Park, E.K.; Jung, H.S.; Yang, H.I.; Yoo, M.C.; Kim, C.; Kim, K.S. Optimized THP-1 differentiation is required for the detection of responses to weak stimuli. Inflamm. Res. 2007, 56, 45-50. [CrossRef] [PubMed]

42. Li, Z.H.; Si, Y.; Xu, G.; Chen, X.M.; Xiong, H.; Lai, L.; Zheng, Y.Q.; Zhang, Z.G. High-dose PMA with RANKL and MCSF induces THP-1 cell differentiation into human functional osteoclasts in vitro. Mol. Med. Rep. 2017, 16, 8380-8384. [CrossRef] [PubMed] 